\title{
Lama Perendaman Benih Sawi Hijau (Brassica rapa var. parachinensis) Dalam Larutan Mikroorganisme Lokal (MoL) Bonggol Pisang Kepok (Musa paradisiaca L.) Terhadap Viabilitas Benih
}

\author{
Inri $^{1)}$, Sepling Paling ${ }^{2)}$, Ida Alua ${ }^{3)}$ \\ 1) Staf Pengajar Prodi Agroteknologi STIPER Petra Baliem Wamena, Jayawijaya, Papua \\ 2) Staf Pengajar Prodi Pendidikan Matematika STKIP Kristen Wamena, Jayawijaya, Papua \\ 3) Mahasiswa Prodi Agroteknologi STIPER Petra Baliem Wamena, Jayawijaya, Papua \\ E-mail: ${ }^{1)}$ inrianticute@yahoo.com
}

\begin{abstract}
ABSTRAK
Tanaman sawi hijau merupakan salah satu tanaman sayur-sayuran yang bernilai ekonomis tinggi, sehingga diperlukan suatu perlakuan teknologi budidaya agar produksi tanaman sawi hijau tidak menurun. Untuk mengatasi hal tersebut diperlukan penggunaan benih yang berkualitas melalui peningkatan viabilitas benih yand diintegrasikan dengan agen hayati yaitu mikroorganisme lokal dari bonggol pisang. Tujuannya untuk mencegah kerusakan benih akibat adanya fungi atau cendawan, dan untuk mematahkan dormansi pada benih karena penyimpanan yang terlalu lama. Pada akhirnya dapat mempercepat perkecambahan benih sawi hijau. Penelitian ini dilakukan di kampung Pikhe, Wamena menggunakan rancangan acak lengkap (RAL) dengan 6 perlakuan dan 4 ulangan. Hasil penelitian membuktikan bahwa perendaman 2 jam, 4 jam, dan 6 jam menunjukkan potensi tumbuh benih dan daya berkecambah beni yang paling cepat. Namun demikian perendaman 6 jam paling direkomendasikan karena menunjukkan viabilitas benih yang paling baik. Sedangkan perendaman benih selama 8 jam dan 10 jam tidak menunjukkan viabilitas benih yang baik. Untuk itu, disarankan untuk melakukan perendaman benih sawi hijau selama 6 jam sebelum ditanam dan tidak direkomendasikan untuk melakukan perendaman lebih dari 10 jam karena hal ini dapat berpengaruh buruk terhadap viabilitas benih sawi hijau.
\end{abstract}

Kata Kunci: Sawi hijau, Perendaman, Mikroorganisme Lokal, Viabilitas, Pisang Kepok

\section{Pendahuluan}

Peningkatan kualitas benih menjadi salah satu hal penting harus dilakukan guna meningkatkan produksi dan produktifitas tanaman yang dibudidayakan. Salah satu jenis tanaman yang menjadi perhatian masyarakat dan perlu ditingkatkan kualitas produksinya adalah tanaman Sawi Hijau (Brasicca rapa var.parachinensis).
Tanaman sawi hijau merupakan bahan makanan sayuran yang mengandung zat gizi yang cukup lengkap sehingga mengkonsumsi daun sawi hijau dapat mempertahankan kesehatan tubuh. Menurut Direktorat Gizi Departemen Kesehatan RI (1981) bahwa sawi hijau mengandung protein, lemak, karbohidrat, $\mathrm{Ca}, \mathrm{P}$, $\mathrm{Fe}$, Vitamin A, Vitamin B, dan Vitamin C. Selain itu, 
mengkonsumsi tanaman sawi hijau dipercaya dapat menghilangkan rasa gatal pada tenggorokan karena batuk, menghilangkan sakit kepala, dan dapat membersihkan darah (Haryanto et al., 2003).

\section{Melihat}

begitu

bermanfaatnya tanaman sawi hijau sehingga produksi tanaman sawi hijau perlu ditingkatkan karena selama ini produksi dan produktifitas tanaman sawi hijau semakin menurun (Karsono et al., 2002).

\section{Untuk mengatasi}

menurunnya produksi tanaman sawi hijau maka diperlukan penggunaan benih bermutu tinggi. Dengan demikian teknik budidaya khususnya pada perlakuan dan persiapan benih sangat penting dilakukan. Tujuannya adalah untuk mengatasi munculnya permasalahan dormansi fisiologis pada benih setelah pemanenan (Sutariati et al., 2014).

Teknologi budidaya yang diperlukan dalam mengatasi masalah tersebut adalah teknologi benih yang berkaitan dengan peningkatan viabilitas benih yang diintegrasikan dengan agen hayati yaitu mikroorganisme yang mampu berperan sebagai biofertilizer dan biopestisides) (Loon, 2007). Mikroorganisme yang digunakan adalah mikroorgansime lokal yang diambil dari bonggol pisang kepok yang tumbuh disekitar areal pertanian di kampung Pikhe distrik
Pisugi, Wamena Kabupaten Jayawijaya, Papua.

Bonggol pisang mengandung tujuh mikroorganisme yang sangat berguna bagi tanaman yaitu Azospirillium, Azotobacter, Bacillus, Aeromonas, Aspergillus, mikroba pelarut phospat dan mikroba selulotik. Tidak hanya itu, mikroorganisme bonggol pisang juga tetap bisa digunakan untuk bioaktivator atau mempercepat proses pengomposan (Khaerul, 2001; Joo et al., 2004; Damayanti, 2013; Budiyani, et al., 2016).

Jenis pisang yang digunakan dalam penelitian ini adalah pisang kepok. Menurut Sunarjono (2004) menyatakan bahwa tanaman pisang kepok merupakan tanaman yang cepat menghasilkan, tahan lama, mudah ditanam, dan mudah dipelihara. Hampir seluruh bagian dari tanaman pisang kepok dapat dimanfaatkan seperti daun, batang, buah, bunga (rias), dan bonggolnya. Namun, bagian bonggollah yang paling jarang digunakan dan seringkali dibiarkan begitu saja setelah tanaman pisang dipanen. Pemanfaatan bonggol pisang saat ini masih sangat terbatas misalnya bonggol pisang dapat dibuat camilan seperti keripik bonggol pisang dan pembuatan alkohol melalui fermentasi.

Selain kanndungan gizi yang tinggi, bonggol pisang juga mengandung mikrobia pengurai bahan organik. Mikrobia pengurai 
tersebut terletak pada bonggol pisang bagian luar maupun bagian dalam (Suhastyo, 2011).

Kandungan gizi bonggol pisang berpotensi digunakan sebagai sumber Mikroorganisme Lokal (MoL) karena kandungan gizi dalam bonggol pisang dapat digunakan sebagai sumber makanan sehingga mikrobia berkembang dengan baik. MoL merupakan salah satu dekomposer yang dapat digunakan untuk mendekomposisi unsur-unsur hara organik yang terdapat dalam tanah sehingga akar tanaman mudah menyerap unsurunsur hara tersebut.

MoL merupakan salah satu dekomposer yang sedang berkembang pesat pada sistem pertanian organik saat ini. Penelitian tentang MoL sangat diperlukan dalam rangka menghasilkan karya ilmiah yang dapat diterapkan sebagai teknologi tepat guna bagi petani dan untuk menerapkan sistem pertanian organik untuk menciptakan produk pertanian yang berkualitas dan sehat serta menciptakan pertanian yang berkelanjutan.

Berdasarkan keberagaman manfaat dari MoL bonggol pisang, maka pada penelitian ini, peneliti mencoba untuk melakukan peningkatan kualitas benih pada tanaman sawi hijau dengan melakukan pengintegrasian benih dengan MoL bonggol pisang kepok. Kandungan mikroba dari MoL bonggol pisang diyakini dapat melindungi benih dari kerusakan karena fungi atau cendawan serta dapat mematahkan dormansi pada benih sawi hijau yang telah lama disimpan sehingga dapat mempercepat perkecambahan benih sawi hijau setelah direndam dengan variasi waktu yang telah ditentukan. Untuk itu, penelitian ini bertujuan untuk mengetahui waktu perendaman benih sawi hijau yang tepat dalam meningkatkan viabilitasnya, sehingga dengan viabilitas yang tinggi dapat meningkatkan kualitas benih sawi hijau.

\section{Metode Penelitian}

Jenis penelitian yang dilakukan adalah penelitian eksperimen dengan menggunakan Rancangan Acak Lengkap (RAL) dengan 6 perlakukan dan 4 replikasi. Kriteria perlakuan yang dilakukan dalam penelitian ini adalah waktu yang digunakan dalam perendaman benih sawi hijau. Waktu yang ditentukan untuk perendaman adalah 0 jam, 2 jam, 4 jam, 6 jam, dan 8 jam, 10 jam dan konsentrasi larutan yang digunakan dalam perendaman adalah $40 \mathrm{ml}$ MoL dicampur $100 \mathrm{ml}$ air bersih.

Populasi dalam penelitian ini adalah tanaman sawi hijau yang ditanam pada plot-plot yang telah disiapkan yang terdiri dari 24 plot (plot menggunakan wadah jergen 5 liter yang dibelah menjadi 2 bagian 
memanjang). Luas permukaan jergen setelah dipotong adalah 26 $\mathrm{cm} \times 17 \mathrm{~cm}$. Penentuan jumlah plot dilakukan dengan cara menghitung jumlah perlakuan $\mathrm{x}$ jumlah replikasi. Tiap plot terdiri dari 20 benih sawi hijau yang ditanam dengan jarak $5 \mathrm{~cm}$ x $4 \mathrm{~cm}$. Dengan demikian banyaknya populasi pada seluruh plot yaitu 480 benih sawi hijau.

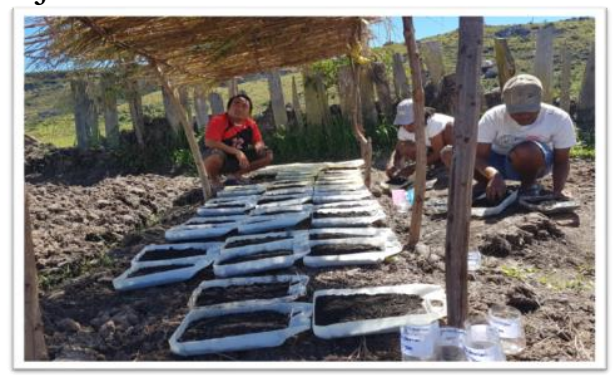

Gambar 1. Plot-Plot Benih

\section{Pelaksanaan}

1. Persiapan media

Persiapan media dilakukan selama 1 minggu sebelum perkecambahan (persemaian). Media tanah yang akan digunakan dihancurkan secara manual lalu di masukkan dalam wadah jergen yang telah disiapkan. Setelah itu, tanah dalam media dilembabkan dan dibiarkan selama 1 minggu.

2. Pembuatan MoL

Cara membuat MoL bonggol pisang sebagai berikut:

a. Pertama-tama menggali bonggol pisang, bonggol pisang yang dipilih adalah bonggol pisang yang masih sudah panen namun masih hidup dan segar. Jenis bonggol pisang yang digunakan adalah bonggol pisang Kepok.

b. Mencuci bersih bonggol pisang yang telah digali.

c. Mencincang halus bonggol pisang lalu ditimbang sebanyak $1 \mathrm{~kg}$.

d. Merebus air untuk melarutkan gula pasir sebanyak $500 \mathrm{~g}$.

e. Menyiapkan air cucian beras sebanyak 2,5 liter.

f. Menyiapkan media untuk fermentasi yaitu jergen 5 liter, selang, dan botol air mineral yang telah diisi dengan air bersih sebanyak $500 \mathrm{ml}$.

g. Mencampur semua bahan dalam media fermentasi (jergen) lalu mengaduknya atau menggoyanggoyangkannya hingga tercampur dengan sempurna.

h. Merangkai media fermentasi.

i. Menyimpan MoL yang sudah dibuat selama 20 hari.

3. Perendaman benih

Perendaman benih dilakukan secara bertahap mulai dari yang paling lama yaitu 10 jam. Setelah perendaman 2 jam berlalu, maka melakukan perendaman benih yang diberi perlakukan 8 jam, demikian seterusnya hingga benih yang direndam 0 jam dan siap untuk dikecambahkan pada media yang telah disiapkan. 
4. Persemaian / Perkecambahan Benih sawi hijau yang telah direndam selama waktu yang telah ditentukan, kemudian dikecambahkan/disemaikan pada media yang telah disiapkan.

5. Pemberian label (labelling)

Pemberian label pada plotplot/media tanam dilakukan sehari sebelum persemaian. Tujuan pemberian label adalah untuk membedakan perlakuan yang akan diberikan pada masing-masing tanaman sawi hijau.

6. Pemeliharaan

a. Penyiraman

Penyiraman dilakukan 2 kali sehari jika media tanah mengalami kekeringan. Akan tetapi jika kondisi tanah masih lembab maka penyiraman tidak dilakukan. Penyiraman dilakukan dengan menggunakan sprayer.

b. Penyiangan

Penyiangan dilakukan saat tanaman berumur 5-7 hst dan pelaksanaannya dilakukan secara manual yaitu mencabut rumput atau gulma dengan menggunakan tangan.

7. Pengukuran/Pengamatan

Pengukuran dilakukan pada hari ke 5 dan hari ke 7 setelah persemaian dilakukan.

\section{Analisis Data}

Data hasil pengukuran yang telah diperoleh kemudian dianalisis dengan menggunakan rumus Indriyanto untuk menentukan persentase jumlah benih yang berkecambah $(G)$ dan persentase daya berkecambah benih (DB). Selanjutnya untuk mengetahui adanya pengaruh konsentrasi MoL dalam perendaman benih terhadap jumlah benih yang berkecambah (potensi perkecambahan) dan daya berkecambah benih sawi hijau maka dilakukan Analisis of Varian (ANOVA) yaitu One Way Anova (Anova Satu Arah) dengan taraf signifikansi 5\%. Persyaratan uji Anova adalah Uji Normalitas Data dan Uji Homogenitas Data. Jika terdapat pengaruh yang nyata maka dilanjutkan dengan Duncan's Multiple Rank Test (DMRT) untuk mengetahui konsentrasi MoL mana yang memiliki pengaruh lebih baik dibandingkan dengan perlakuan lainnya.

\section{Hasil Penelitian}

Viabilitas suatu benih merupakan daya hidup suatu benih yang dapat ditunjukkan oleh proses pertumbuhan benih sedangkan viabilitas potensial merupakan parameter viabilitas dari suatu benih yang menunjukkan kemampuan benih menumbuhkan tanaman normal yang berproduksi normal pada kondisi lapang yang optimum. Perendaman benih dengan menggunakan MoL yang berasal dari bonggol pisang kepok dilakukan untuk mengetahui waktu 
perendaman yang optimal dan tepat yang dapat menunjang potensi tumbuh dan daya berkecambah suatu benih.

Tabel 1. Uji Duncan's Pengaruh Perendaman Terhadap Potensi Tumbuh Benih

\begin{tabular}{crrrrrr}
\hline \multirow{2}{*}{ Indikator } & \multicolumn{5}{c}{ Lama Perendaman } \\
\cline { 2 - 6 } & 0 jam & 2 jam & 4 jam & 6 jam & 8 jam & 10 jam \\
\hline Potensi & $87,50^{\mathrm{bc}}$ & $92,50^{\mathrm{c}}$ & $95,00^{\mathrm{c}}$ & $95,00^{\mathrm{c}}$ & $83,75^{\mathrm{ab}}$ & $77,50^{\mathrm{a}}$ \\
Tumbuh & & & & & &
\end{tabular}

Keterangan: Huruf yang berbeda menunjukkan ada perbedaan antara perlakuan yang satu dengan perlakuan yang lain.

Berdasarkan hasil ANOVA perlakuan pemberian perendaman benih dengan MoL menunjukkan pengaruh yang berbeda nyata, sehingga dapat dilakukan uji lanjut menggunakan uji Duncan. Hasil analisis anova menunjukkan bahwa nilai $F_{\text {hitung }}$ sebesar $6,490>F_{\text {tabel }}$ 4,250 atau nilai signifikansi hitung indikator potensi berkecambah $0,001<0,05$ dan untuk indikator daya berkecambah memiliki $F_{\text {hitung }}$ sebesar 4,554 > $\mathrm{F}_{\text {tabel }} 4,250$ atau nilai signifikansi hitung $0,007<$ 0,05 sehingga demikian kedua indikator tersebut dapat dikatakan bahwa terdapat pengaruh lama perendaman terhadap perkecambahan benih sawi hijau. Untuk itu, dapat dilanjutkan ke Uji Duncan's untuk mengetahui perlakuan mana yang lebih berpengaruh atau berbeda nyata.

Tabel 2. Uji Duncan's Pengaruh Perendaman terhadap Daya Berkecambah Benih

\begin{tabular}{lcccccc}
\hline \multirow{2}{*}{ Indikator } & 0 jam & 2 jam & 4 jam & 6 jam & 8 jam & $\begin{array}{l}10 \\
\text { jam }\end{array}$ \\
\cline { 2 - 6 } & $83,75^{\mathrm{b}}$ & $91,52^{\mathrm{b}}$ & $92,50^{\mathrm{b}}$ & $95,00^{\mathrm{b}}$ & $76,25^{\mathrm{ab}}$ & $57,50^{\mathrm{a}}$ \\
\hline $\begin{array}{l}\text { Daya } \\
\text { Berkecambah }\end{array}$ & $\begin{array}{l}\text { Keterangan: Huruf yang berbeda menunjukkan ada perbedaan antara perlakuan yang satu } \\
\text { dengan perlakuan yang lain. }\end{array}$
\end{tabular}

Histogram potensi dan daya berkecambah benih tanaman sawi hijau yang di beri perlakuan perendaman dengan beberapa level waktu lama perendaman yang berbeda-beda dapat dilihat pada gambar berikut: 


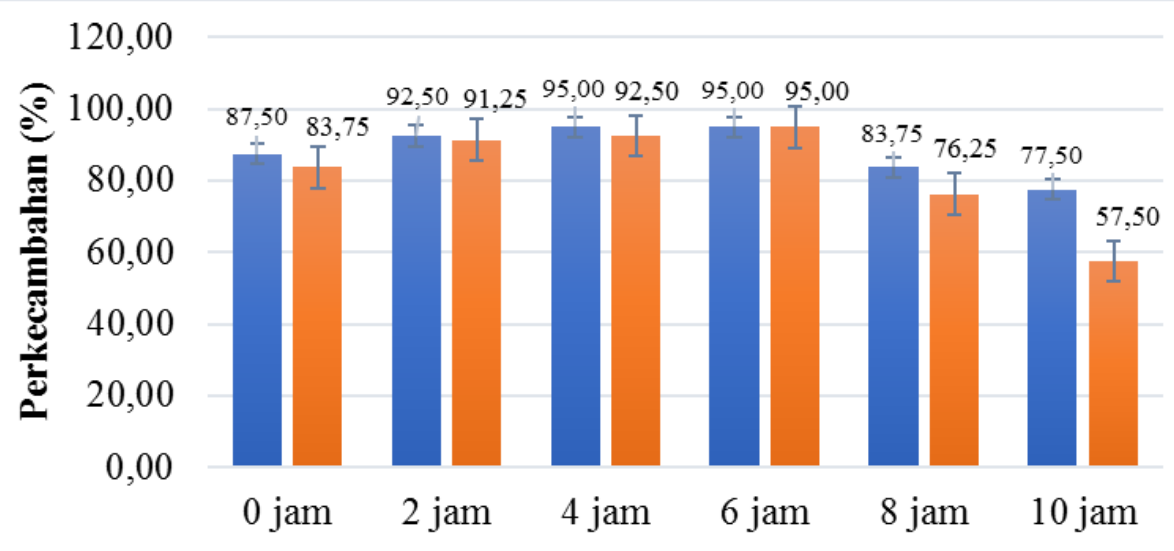

Lama Perendaman

Rerata (\%) Potensi Berkecambah $\backsim$ Rerata (\%) Daya Berkecambah

Gambar 2: Potensi dan Daya berkecambah benih sawi hijau setelah perendaman dengan waktu tertentu

\section{Pembahasan}

\section{Potensi Tumbuh Benih Setelah Perendaman}

Data pada tabel 1 menunjukkan lama waktu perendaman memberikan pengaruh pada semua perlakuan. Dari enam perlakuan lama perendaman yaitu 0 jam, 2 jam, 4 jam, 6 jam, 8 jam dan 10 jam, perlakuan dengan perendaman 2 jam, 4 jam dan 6 jam menunjukkan potensi tumbuh yang paling baik di bandingkan dengan perlakuan perendaman 0 jam, 8 jam dan 10 jam. Perlakuan 0 jam memiliki potensi tumbuh yang paling rendah dimungkinkan karena tidak adanya pengaruh dari MoL sehingga pertumbuhannya tidak optimal. Dan untuk perendaman 8 dan 10 jam memiliki potensi

pertumbuhan yang lebih baik dibandingkan dengan 0 jam kemungkinan karena adanya efek perendaman dengan MoL membuat pertumbuhannya lebih baik. Namun jika dibandingkan dengan perlakuan yang menggunakan MoL lainnya seperti perlakuan 2 jam, 4 jam dan 6 jam, perlakuan perendaman 8 dan 10 jam menunjukkan potensi pertumbuhan yang lebih rendah. Hal ini kemungkinan proses perendaman yang terlalu lama menyebabkan benih menjadi jenuh air sehingga mempengaruhi potensi tumbuhnya. Sesuai dengan pernyataan Schmidt (2000) yang menjelaskan bahwa ada resiko 
benih akan mati jika dibiarkan dalam air sampai seluruh benih menjadi permeabel. Jadi dalam penelitian ini perendaman yang terlalu lama yaitu dilakukan lebih dari 8 jam dan 10 jam tidak direkomendasikan.

Perendaman dengan larutan MoL berpengaruh terhadap potensi tumbuh benih dikarenakan adanya unsur-unsur hara yang dapat membantu merangsang pertumbuhan. Larutan MoL mengandung unsur makro dan mikro, serta mengandung bakteri yang berpotensi sebagai perombak bahan organik, perangsang pertumbuhan dan agen pengendali hama dan penyakit tanaman, sehingga MoL dapat digunakan sebagai pendekomposer, pupuk hayati dan sebagai pestisida organik terutama sebagai fungisida.

\section{Daya Berkecambah Setelah Perendaman}

Daya berkecambah suatu benih dipengaruhi juga oleh air. Seperti yang diketahui air merupakan faktor lingkungan yang berpengaruh terhadap proses perkecambahan benih (Sadjad, 1975). Oleh karenanya proses perendaman dapat dijadikan sebagai salah satu cara pematahan dormansi benih. Perlakuan perendaman dalam air mengalir berfungsi untuk mencuci zat-zat yang menghambat perkecambahan dan dapat melunakkan kulit benih.
Perendaman dapat merangsang penyerapan lebih cepat.

Berdasarkan hasil analisis uji Duncan pada tabel 2 menunjuukkan bahwa daya berkecambah paling baik terdapat pada perlakuan perendaman 2 jam, 4 jam dan 6 jam. Hasil uji tersebut juga menunjukkan adanya perbedaan antar perlakuan lama perendaman 0 jam, 2 jam, 4 jam, 6 jam dengan lama perendaman 8 jam dan 10 jam. Abjad yang berbeda menunjukkan adanya perbedaan antara perlakuan yang satu dengan perlakuan yang lain.

Berdasarkan pada gambar 2 menunjukkan bahwa dari enam perlakuan yang ada dapat dilihat perlakuan terbaik terdapat pada perendaman 2 jam, 4 jam dan 6 jam. Dari ketiga perlakuan terbaik daya berkecambah tertinggi terdapat pada perlakuan dengan lama perendaman 6 jam yaitu dengan persentase daya berkecambah mencapai 95\%. Data potensi berkecambah selaras dengan daya berkecambah, dimana potensi berkecambah tertinggi juga terdapat pada perlakuan dengan waktu lama perendaman 6 jam menunjukkan hasil yang paling optimal.

Dengan demikian dapat dikatakan bahwa pemberian larutan MoL bonggol pisang untuk perendaman benih terbukti memiliki pengaruh positif terhadap potensi tumbuuh dan daya berkecambah benih. Selain dapat merangsang pertumbuhan, larutan MoL bonggol 
pisang juga dapat membuat tanaman toleran terhadap penyakit. Hal ini yang menyebabkan tingginya daya berkecambah pada benih yang telah di beri perlakuan perendaman dengan MoL yang berkisar dari 91$95 \%$.

\section{Kesimpulan}

Pengaruh proses lama perendaman MoL untuk mendukung potensi tumbuh benih tanaman sawi hijau (Brassica rapa var. parachinensis) menunjukkan pengaruh yang berbeda nyata. Pengaruh lama perendaman dengan MoL yang memiliki potensi tumbuh dan daya berkecambah yang paling baik terdapat pada perlakuan 2 jam, 4 jam dan 6 jam sehingga dapat dijadikan sebagai rekomendasi lama waktu perendaman yang baik. Namun demikian, peneliti merekomendasikan perendaman benih dengan waktu 6 jam karena hasil penelitian membuktikan bahwa perendaman benih sawi hijau selama 6 jam menunjuukkan potensi tumbuh dan daya berkecambah benih yang lebih baik jika dibandingkan dengan perendaman 2 jam dan 4 jam. Selain itu, peneliti tidak merekomendasikan untuk melakukan perendaman bnih sawi hujau lebih dari 10 jam.

\section{Saran}

Perlu adanya pengukuran unsur hara makro dan mikro pada MoL bonggol pisang kepok, dan perlu dilakukan identifikasi jenis mikroba sehingga diketahui mikroba yang terdapat dalam MoL tersebut dengan menggunakan medium yang spesifik.

\section{DAFTAR PUSTAKA}

Budiyani, Ni Komang, Ni Nengah Soniasari, dan Ni Wayan Sri Sutari. 2016. Analisis Kualitas Larutan Mikroorganisme Lokal (MoL) Bonggol Pisang. EJurnal Akroekoteknologi Tropika Vol. 5 No. 1.

Damayanti, P.A. 2013. Kandungan Kimia Pupuk Organik Cair dari Urine Sapi Menggunakan Biang PGPR (Plant Growth Promoting Rhizobacteria) Batang Pisang Sebagai Pengganti EM4. Fakultas Keguruan dan Ilmu Pendidikan Universitas Muhammadiyah Surakarta. Surakarta.

Direktorat Gizi Departemen Kesehatan Republik Indonesia. 1981. Daftar Komposisi Bahan Makanan, Bhatara Karya Aksara: Jakarta.

Haryanto, W., T. Suhartini dan E. Rahayu. 2003. Sawi dan Selada Edisi Revisi, Penebar Swadaya: Jakarta.

Joo, G. J., Kim., Lee, I. J., Song K. S, Rhee, I. K. 2004. Growth Promotion of Red Pepper Plug Seedling and the Production of Gibberelins the plant growth of Micropropageted Bananas. 
Karsono, S., Sudarmodjo dan Sutiyoso. 2002. Hidroponik Skala Rumah Tanga. Agro Media Pustaka.

Khaerul, U. 2001. Pemanfaatan Bioteknologi Untuk meningkatkan Produksi pertanian. Progaram pascasarjana / S3 Institut Pertanian Bogor. Bogor. (http://tumoutou.net/3_seml_01 2/u_khairul.html). (Diakses Tanggal 29 Oktober 2012).

Loon LC. 2007. Plant responses to plant growth-promoting rhizobacteria. Eur J. Plant Pathology, 119:243-254.

Sadjad, S. 1975. Proses Metabolisme Perkecambahan Benih dalam Dasar-dasar Teknologi Benih. Buku. Capita selekta.

Departemen Agronomi.. Institut Pertanian Bogor. Bogor. 138 p.
Schmidt, L. 2000. Pedoman penanganan benih hutan tropis dan subtropis 2000 (terj.). Direktorat Jenderal Rehabilitasi Lahan dan Perhutanan Sosial. Departemen Kehutanan.

Sutariati GAK, Zul'aiza, Darsan S, Kasra LMA, Wangadi S, Mudi L. 2014. Invigorasi Benih Padi Gogo Lokal Untuk Meningkatkan Vigor Dan Mengatasi Permasalahan Dormansi Fisiologis Pascapanen.

Suhastyo, A. A. 2011. Studi Mikrobiologi dan Sifat Kimia Mikroorganisme Lokal yang Digunakan pada Budidaya Padi SRI (System of Rice Intensification). Sekolah Pascasarjana. Institut Pertanian Bogor. Bogor.

Sunarjono, H. H. 2004. Bertanam 30 Jenis Sayur, Jakarta: Penebar Swadaya. 